\title{
Form Analysis Sebagai Metode Kritik Matan: \\ Menakar Keakuratan Pemikiran Robert Marston Speight (1924-2011)
}

(Form Analysis as a Method of Matn Criticism: Scrutinizing the Accuracy of Robert Marston Speight's Thought (1924-2011))

\section{Arif Chasanul Muna}

Institut Agama Islam Negeri (IAIN) Pekalongan, Indonesia

arif_chasanul_muna@yahoo.com

DOI: $10.29240 /$ alquds.v5i1.1895

Submitted: 2020-08-24 | Revised: 2021-03-09 | Accepted: 2021-04-03

\begin{abstract}
Together with sanad, matn is the main component in a hadith. Among the important discussions regarding matn is the existence of several matn which have different editorials while informing one incident. This problem is usually called the problem of matn with various versions (ta'addud al-riwāyāt; variant version). In the West, this problem has received the attention of many academics, among them Robert Marston Speight. He offers a form analysis method for studying and researching the problem of matn with various versions. This paper systematically describes how the Speight analysis method is, and how its position is in the study of hadith in the West. Critical analysis of the Speight method was also carried out by comparing it with the views of other academics and also the views of muhaddis̄un. This paper uses a qualitative method in the form of a research library with a critical analysis model. This paper shows several conclusions: the method of analysis used by Speight, namely form analysis, is the development of the method of analysis of the matn which has been introduced, especially by Schacht with the purposes of dating tradition; many academics both in the West and the East doubted Speight's method of analysis and criticized its accuracy; and when compared to the muhaddisiun method, the Speight method contains several methodological flaws.
\end{abstract}

Keywords: form analysis, matn criticism, various versions of matn, R. Marston Speight

Abstrak. Bersamaan dengan sanad, matan merupakan komponen utama dalam sebuah hadis. Di antara pembahasan penting mengenai matan adalah keberadaan matan yang redaksinya berbeda-beda padahal menginformasikan satu kejadian. Masalah ini biasa disebut dengan problem matan beragam versi (ta'addud al-riwāyāt; variant version). Di Barat permasalahan ini menjadi perhatian banyak akademisi, di antaranya adalah Robert Marston Speight. Dia menawarkan metode form analysis untuk mengkaji dan meneliti problem matan beragam versi ini. Tulisan ini menjelaskan secara sistematis bagaimana metode analisis Speight tersebut, dan bagaimana posisinya dalam peta kajian hadis di 
Barat. Analisis kritis terhadap metode Speight juga dilakukan dengan cara membandingkannya dengan pandangan akademisi lain dan juga pandangan muhaddis̀ūn. Tulisan ini menggunakan metode kualitatif, berbentuk library research dengan model analisis kritis. Hasil yang ditemukan adalah metode analisis yang digunakan Speight yaitu form analysis, adalah pengembangan metode analisis matan yang sudah digagas sebelumnya terutama oleh Schacht untuk keperluan penanggalan hadis (dating tradition); banyak akademisi baik di Barat maupun Timur, yang meragukan metode analisis Speight dan mengkritisi keakuratannya; dan apabila dibandingkan dengan metode muhaddišūn, metode Speight mengandung beberapa kelemahan metodologis.

Keyword: form analysis, kritik matan, matan beragam versi, R. Marston Speight

\section{Pendahuluan}

Matan beragam versi (ta'addud al-riwàyāt) menjadi tema menarik yang terus diteliti oleh para akademisi hingga saat ini. Keberadaan matan yang redaksinya beragam, padahal membicarakan satu hal yang sama, sudah barang tentu menimbulkan pertanyaan-pertanyaan bahkan kecurigaan berkaitan dengan keasliannya. Pertanyaan yang paling awal muncul tentunya adalah bagaimana hal itu bisa terjadi dan siapakah yang berperan dalam proses perubahan matan tersebut. Pertanyaan lain yang tidak kalah pentingnya adalah metode apakah yang tepat yang bisa digunakan untuk mengidentifikasi dan menjawab problem tersebut.

Di dunia Islam permasalahan ini mendapat perhatian serius dari beberapa ulama. Di antaranya adalah Syaraf al-Qudāh dan Amīn al-Qudāh yang menulis buku dengan judul Asbāb Ta'addud al-Riwwāyàt fì Mutūn al-Hadìs al-Nabawì al-Syarîf. Dalam bukunya, ia menerangkan faktor yang melatar belakangi munculnya redaksi matan dengan ragam versi yang berbeda. ${ }^{1}$ Sementara itu Mājid al-'Alyawī dalam disertasinya berjudul Ta'addud Riwàyāt al-Hadìs al-Nabawì wa Ásaruh fì Ikhtiläf alMuhaddisin fi al-Hukm 'alà al-Hadis: Dirāsah Ta'shiliyyah membahas dampak yang ditimbulkan dari keberadaan matan beragam versi terhadap munculnya perbedaan pendapat dalam penetapan status kualitas hadis. Satu kajian yang tidak kalah menarik dan cukup komprehensip membahas permasalahan ta'addud al-riwāyāt adalah yang dilakukan oleh Shayuthy b. Abdul Manas. Selain membahas faktor penyebab munculnya perbedaan redaksi matan, dalam disertasinya berjudul Ta'addud al-Riwāyàt fì Matn al-Hadìs al-Nabawi Asbäbubu wa Āं́̄̄rubu, Shayuthy juga menjelaskan pengaruh ta'addud al-riwāyāt terhadap pembahasan dalam disiplin ilmu hadis, pemahaman hadis, ilmu usul fiqh dan ilmu fiqh. ${ }^{2}$

${ }^{1}$ Lihat Syaraf al-Qudāh dan Amīn al-Qudāh, Asbāb Ta'addud al-Rìwāyàt fì Mutūn al-Hadìs al-Nabawì al-Syarif (Jordan: Dār al-Furqān, 1985).

${ }^{2}$ Lihat Shayuthy b. Abdul Manas, Ta'addud al-Riwāyāat fì Matn al-Hadìs al-Nabawì Asbābuhu wa Āśärubu (Disertasi Doktor IIUM, 2004). 
Berbeda dengan di dunia Islam, kajian di Barat mengenai matan beragam versi lebih cenderung bersifat kritikan. Perdebatan yang terjadi berlangsung dinamis dan berkesinambungan. Dinamis karena masing-masing akademisi menawarkan metode analisis yang berbeda-beda, dan berkesinambungan, karena satu pendapat dan metode yang ditawarkan merupakan respon, perbaikan dan juga kritik atas pendapat dan metode sebelumnya. Di antara orientalis klasik yang terlibat dalam perdebatan ini adalah Eric F. F. Bishop dalam artikelnya yang berjudul "Form Criticsm and The Forty-Two Tradition of an-Nawawi" (terbit 1940). ${ }^{3}$ Artikel ini menganalisis empat puluh dua hadis dalam kitab al-Arba'in karya Imam al-Nawawī (631-676 H) dengan menggunakan metode Form Criticsm. Metode analisis matan beragam versi seperti ini kemudian dikembangkan oleh akademisiakademisi Barat berikutnya hingga masa kontemporer saat ini yang diwakili oleh Harald Motzki dan Herbert Berg yang menawarkan beberapa metode baru untuk menangani masalah ini. ${ }^{4}$

Selain nama-nama di atas nama yang sangat penting dan tidak bisa ditinggalkan dalam perdebatan matan yang beragam versi di Barat adalah $\mathrm{R}$. Marston Speight. Hasil penelitiannya diringkas dalam tulisan berjudul "The Will of Sa'd b. Abi Waqqäs: The Growth of Tradition" dan "A Look at Varian Readings in the Hadis $^{\prime 0}$ dan yang lain sangat penting dalam kajian hadis di Barat. Sebab [1] Speight berhasil membangun satu corak tersendiri dalam pendekatan analisis matan beragam versi yang kemudian diikuti oleh banyak pemerhati hadis di Barat, dan [2] Tulisan Speight merupakan jembatan yang menghubungkan kajian klasik dan kontemporer di Barat mengenai matan beragam versi. Dia memperbaiki dan memperjelas kajian-kajian sebelumnya, dan hasil penelitiannya kemudian dijadikan dasar pijakan oleh akademisi barat setelahnya untuk mengkonstruk metode baru yang dianggap lebih reliable.

${ }^{3}$ Lihat Eric F. F. Bishop, "Form Criticsm and The Forty-Two Tradition of an-Nawawi," The Moslem World, vol 30, 1940, 253-261.

${ }^{4}$ Lihat Harald Motzki, "Quo Vadis Hadi’ Forschung? Eine kritische Untersuchung Von G.H.A Juynboll: Nāfi' Mawlā of Ibn Umar, and His Position in Muslim hadis Literature," Der Islam, vol 73, 1996, 40-80; Harald Motzki, "Dating Muslim Traditions: A Survey," Arabica, vol. LII, no. 2, 2005, 204-253. Lihat juga Herbert Berg, The Development of Exegesis in Early Islam (Surrey: Curzon Press, 2000); dan "Competing Paradigms in the Study of Islamic Origins: Qur'an 15:89-91 and the Value of Isnad" dalam Herbert Berg (ed.), Method and Theory in the Study of Islamic Origins (Leiden: Brill, 2003), 259-292.

${ }^{5}$ R. Marston Speight, "The Will of Sa'd b. Abī Waqqās: The Growth of Tradition," Der Islam, vol 50, 1973, 249-267.

${ }^{6}$ R. Marston Speight, “A Look at Varian Readings in the Hadith” Der Islam, vol. 77, 2000, 169-179. 
Terdapat tiga pokok permasalahan yang menjadi fokus tulisan ini yaitu: [a] Bagaimanakah posisi metode R. Marston Speight dalam kajian hadis di Barat?; [b] Bagaimanakah metode R. Marston Speight dalam menganalisis masalah matan beragam versi (ta'addud al-riwajyat)?; [c] Bagaimanakah tingkat validitas metode yang ditawarkan oleh R. Marston Speight dalam perspektif ilmu hadis? Tulisan ini menggunakan metode kualitatif dan berbentuk library research, oleh sebab itu langkah-langkah penelitian yang sesuai akan dijalankan dalam kajian ini. Langkahlangkah tersebut adalah pengumpulan data dan analisis data. Layaknya penelitian kualitatif, tidak ada garis batas yang jelas tentang kapan dimulainya analisis data. Sebab, sejak data dikumpulkan, maka pada waktu itu juga analisis data mulai dilakukan.

\section{Sekilas Biografi Robert Marston Speight}

Robert Marston Speight Lahir di Littlefield, Texas pada tanggal 15 Oktober 1924, dia adalah putra dari pasangan Robert dan Neva Speight. Semasa mudanya sempat bertugas di Angkatan Laut AS selama Perang Dunia II. Speight menyelesaikan pendidikan sarjananya di Universitas Baylor. Sedangkan program master diselesaikan di The Hartford Seminary pada tahun 1963, dan di lembaga tersebut juga, Speight melanjutkan pada program doktoral dan selesai pada tahun 1970. Judul disertasinya adalah "The Musnad of al-Tayalisi: A Study of Islamic Hadith as Oral Literature"?

Speight aktif sebagai pendeta di United Methodist Church, Amerika. Bersama istrinya, Elizabeth -kelahiran Prancis-, ia sempat melakukan pelayanan gerejawi sebagai misionaris di Afrika Utara selama 28 tahun. Marston Speight juga pernah menjabat sebagai direktur Christian-Muslim Relations of the National Council of Churches of Christ di Amerika Serikat selama 13 tahun dari tahun 1979 sampai 1992. Kiprahnya yang aktif dalam dialog Kristen-Islam mendapatkan penghargaan dari Hartford Seminary pada tanggal 3 Mei 2002. Atas dasar inilah selain terkenal sebagai pengkaji keislaman, Speight juga terkenal sebagai pakar dialog antar agama khususnya dialog antara Kristen dan Islam. Masa-masa akhir kehidupannya ia aktif mengajar di almamaternya yaitu The Hartford Seminary.

Sebagai akademisi, Speight banyak menulis karya ilmiah. Di satu sisi buku dan artikel Speight menunjukkan minatnya pada masalah dialog Kristen-Muslim. Di antranya adalah Chiristian-Muslim Relations: An Introduction for Chiristians in the United States of America (1983); Creating Interfaith Community (2003) ditulis bersama dengan Glory Dharmaraj, Jacob Dharmaraj; dan House of Islam (1969) ditulis bersama Kenneth Cragg. Di sisi lain beberapa artikel Speight yang diterbitkan di berbagai jurnal menunjukkan minatnya yang sangat tinggi terhadap kajian hadis.

175.

${ }^{7}$ Rahile Yilmaz, "Robert Marston Speight," Hadis Tetkikleri Dergisi, vol. 12, no. 1, 2014, 
Selain disertasi, ia banyak menulis artikel terkait dengan kajian hadis. Fokus utama kajian Robert Marston Speight adalah aspek transmisi lisan hadis (oral transmission), analisis struktur dan analisis retoris hadis. Di antara karyanya dalam bidang hadis adalah The Will of Sa'd b. A. Waqqäs: The Growth of a Tradition (Terbit di Der Islam, 1973), Oral Traditions of the Prophet Mubammad: A Formulaic Approach (Terbit di Oral Tradition Journal, 1989), A Look at Variant Readings in the Hadith (Terbit di Der Islam, 2000), Narrative Structure in the Hadith (Terbit di Journal of Near Eastern Studies, 2000), dan Some Formal Characteristic of the Musnad Type of Hadith Collection (Terbit di Arabica: Journal of Arabic and Islamic Studies, 2002). ${ }^{8}$

Setelah mendedikasikan usianya dalam kajian ketimuran khususnya dalam bidang hadis, baik dengan menulis buku, artikel maupun mengajar, dan juga aktif dalam dialog Kristen-Islam utamanya di Amerika, Speight meninggal pada usia 86 tahun pada hari Rabu, 19 Januari 2011 di Cromwell. ${ }^{9}$

\section{Posisi Speight dalam Peta Studi Hadis Modern di Barat}

Untuk menggambarkan posisi pemikiran Robert Marston Sepight dalam peta studi hadis di Barat, setidaknya perlu membahas dua hal berikut ini: [1] sejarah kajian hadis di Barat hingga masa Speight, [2] Potret kajian hadis di Barat pada masa Speight. Pembahasan pertama akan memberi gambaran pondasi dan genealogi pemikiran Speight dalam studi hadis, dan untuk tujuan ini, penulis akan lebih banyak membahas pemikiran Joseph Schacht (1902-1969M.), karena kajian Schacht mempunyai pengaruh yang sangat besar terhadap kajian hadis di Barat pada masa setelahnya, termasuk pada diri Speight. Sedangkan pembahasan kedua akan memberi gambaran posisi pemikiran Speight di tengah berbagai kecendrungan kajian hadis di Barat yang muncul pada masanya. Dengan dua pembahasan ini diharapkan posisi pemikiran dan kecendrungan pemikiran Speight dapat tergambarkan dan dapat dibandingkan dengan kecendrungan pendapat-pendapat akademisi Barat lainnya.

Kajian keislaman di Barat dalam bentuknya yang sederhana sebenarnya muncul sejak awal persinggungan dengan dunia Islam. Sementara itu, kajian hadis secara spesifik baru muncul pada abad ke tujuh belas. Ensiklopedia berbahasa Prancis, "Bibliotheque Orientale" yang terbit pada tahun 1697 M. ditengarai sebagai tonggak awal kajian hadis di Barat. Di dalam Ensiklopedia tersebut, terdapat penjelasan definisi entri hadis yang ditulis oleh Barthélemy d'Herbelot

\footnotetext{
${ }^{8}$ Rahile Yilmaz, "Robert Marston Speight," 2014, 176.

9 Rahile Yilmaz, "Robert Marston Speight," 2014, 175.
} 
(1635-1695 M.). 10 Meski demikian -sebagaimana dijelaskan oleh Fethuddin Beyanuni- kajian keislaman termasuk kajian hadis baru mulai mengalami perkembangan intensif di Barat pada abad ke sembilan belas dan dua puluh masehi. Pada dua abad ini banyak bermunculan akademisi-akademisi Barat yang intens dalam kajian hadis baik di Jerman, Inggris, Prancis maupun Amerika.11

Kajian kritis terhadap hadis di Barat pada dua abad ini ditandai dengan kemunculan karya-karya tokoh orientalis seperti Ignaz Goldziher (1850-1921 M.) dan Christiaan Snouck Hurgronje (1857-1936 M.).12 Namun buku berjudul The Origins of Muhammadan Jurisprudence karya Joseph Schacht (1902-1969) yang terbit pada tahun 1950 dapat dikatakan sebagai puncak kajian kritis terhadap hadis di Barat, sebab ia berhasil menformulasikan secara sistematis pemikiranpemikiran kritis terhadap hadis di Barat pada masa sebelumnya, dan sekaligus menjadi pijakan pengembangan kajian hadis pada masa setelahnya. Pemikiranpemikiran Schacht mendapat apresiasi yang tinggi di kalangan akademisi Barat. H.A.R. Gibb bahkan menegaskan bahwa karya Schacht akan menjadi fondasi bagi kajian hukum Islam pada masa setelahnya, setidaknya di Barat.13

Melalui tulisan-tulisannya, Joseph Schacht secara tidak langsung berhasil menampilkan pemetaan kajian-kajian penting dalam studi hadis yang perlu dikritisi. Di antaranya adalah [1] kajian dekonstruksi terhadap istilah sunnah dan hadis yang biasa digunakan dalam literatur Islam; [2] kajian genealogi asal-usul substansi matan hadis; [3] kajian historis kemunculan sanad di dunia Islam, dan [4] kajian metodologis untuk menentukan awal mula kemunculan dan penyebaran hadis. Dari empat fokus kajian tersebut tiga yang pertama merupakan kritikan terhadap bangunan konsep dan metodologi kajian hadis yang selama ini dikembangkan oleh ahli hadis di dunia Islam. Sedangkan yang terakhir yaitu kajian mengenai metode penentuan awal mula kemunculan hadis (methode of dating traditions) yang merupakan tawaran kreatif akademisi Barat sebagai alternatif pengganti metode kajian hadis yang selama ini berkembang di dunia Islam.

Terkait dengan tema yang terakhir, Joseph Schacht sendiri menawarkan tiga metode untuk menentukan awal mula kemunculan hadis: [1] Argumentum e silentio, yaitu dengan cara menelusuri koleksi kitab paling awal yang menyinggung substansi hadis. Keberadaan hadis secara formal di dalam kitab paling awal dijadikan indikasi bahwa hadis tersebut baru muncul secara formal pada masa itu;

${ }^{10}$ Lihat Ahmad von Denffer, Literature on Hadith in European Languages: A Bibliographi (Leicester, UK: The Islamic Foundation, 1981), 12-14.

${ }^{11}$ Fethuddin Beyanuni, Madkhal ilā al-Istisyrāq al-Mu'āsir wa 'Tlm al-Hadìs (Riyāḍ: Jāmi’ah al-Malik Sa'ūd Press, 1432), 49.

12 Lihat A.J. Wensinck, "The Importance of Tradition for The Study of Islam", The Muslem World, vol 11, 1921, 241-243.

13 H.A.R. Gibb, "The Origins of Muhammadan Jurisprudence by Joseph Schacht (Notice of Books)," Journal of Comparative Legislation and International Law, vol. 33, 1951, 114. 
[2] Backward growth of isnād, yaitu dengan cara mengumpulkan berbagai jalur sanad satu hadis kemudian menentukan common link dalam jaringan sanad tersebut. Keberadaan common link dalam jaringan sanad dijadikan indikasi kuat bahwa pemalsuan hadis terjadi pada masa common link tersebut; [3] Mengkomparasikan ragam redaksi matan hadis yang membicarakan permasalahan yang sama. Perbedaan redaksi matan tersebut kemudian dianalisis kronologi perkembangannya, dan ditentukan awal mula kemunculannya.14

Karya-karya Schacht bersama karya-karya orientalis sebelumnya menjadi pijakan penting para akademisi Barat berikutnya dalam mengembangkan kajian hadis di Barat. Nama-nama seperti John Burton (1921-2005), John Wansbrough (1928-2002), Josef van Ess (lahir 1934 M), G.H.A. Juynboll (1935-2010), Michael Cook (lahir 1940 M), William A. Graham (lahir 1943 M), Gregor Schoeler (lahir 1944 M), Patricia Crone (lahir 1945 M.), Harald Motzki (1948-2019), Herbert Berg dan juga Robert Marston Speight (1924-2011) adalah beberapa nama yang melanjutkan tradisi kritis kajian hadis di Barat. Pendapat dan pandangan mereka memang tidak sepenuhnya sama dengan pandangan Schacht, karena mereka juga banyak mengkritik beberapa tesis Schacht, namun mereka semua mempunyai pendekatan yang sama dalam kajian hadis yaitu skeptical approach (pendekatan skeptis). Melalui tokoh-tokoh tersebut kajian hadis pasca Joseph Schacht terus berkembang. Pembahasan yang banyak mendapat perhatian di kalangan mereka adalah pembahasan tentang metode penanggalan hadis (methode of dating traditions). Sebagaimana telah disinggung, Schacht telah merintis beberapa metode berkenaan masalah ini, yaitu [1] argumentum e silentio; [2] analisis sanad; [3] analisis matan. Ketiga metode ini kemudiannya banyak mendapat dukungan dan juga kritikan oleh Orientalis setelahnya.

Teori argumentum e silentio yang dikenalkan Schacht mendapat tanggapan positif dari G.H.A. Juynboll. Ia mengaplikasikan teori ini dalam beberapa kajiannya.15 M.J. Kister juga menggunakan metode ini dalam beberapa tulisannya, diantaranya adalah dalam artikel berjudul "Pare Your Nails: a Study of an Early Tradition"16 Sementara itu metode analisis sanad -utamanya teori common link- yang dikembangkan Schacht juga dikembangkan oleh akademisi Barat setelahnya. Di antara yang mengembangkan teori common link berbasis analisis jaringan sanad pasca Schacht adalah Josef van Ess dan G.H.A Juynboll.

14 Harald Motzki, "Dating Muslim Traditions: A Survey," 2005, 211.

${ }_{15}$ G.H.A. Juynboll, Muslim Tradition: Studies in Chronology, Provenance and Authorship of Early Hadith (Cambridge: Cambridge University Press,1983), 47.

${ }^{16}$ Lihat M.J. Kister "Pare Your Nails: a Study of an Early Tradition," Journal of the Ancient Near Eastern Society of Columbia University, vol. 11, 1979, 63-70. 
Sementara itu metode penentuan kemunculan hadis dengan basis analisis matan yang dikenalkan Schacht juga menginspirasi para pangkaji hadis di Barat pada masa setelahnya. Di antaranya adalah William A. Graham dalam bukunya berjudul Divine and Prophetic Word in Early Islam: A Reconsideration of The Source, with Special Reference to the Divine Saying or Hadith Qudsi. Grahamn melakukan kajian terhadap hadis-hadis qudsī, dan sampai pada kesimpulan bahwa hadis-hadis tersebut mucul belakangan dan kebanyakan kandungannya adalah bersumber dari Taurat, Injil dan juga pemikiran filsafat Helenistik.

Robert Marston Speight juga termasuk akademisi yang mengembangkan metode penentuan kemunculan hadis dengan basis analisis matan. Artikelnya yang berjudul "The Will of Sa'd b. Abì Waqqās: The Growth of Tradition" memaparkan metode yang ia gunakan dalam upaya merekonstruksi kemunculan dan perkembangan hadis tentang batasan wasiyat satu pertiga. Ia membandingkan berbagai versi redaksi hadis tersebut, dan sampai pada kesimpulan bahwa hadis tersebut muncul pada masa Umawiyyah, bukan pada masa Nabi.17

Terkait dengan peta metode penanggalan hadis (dating tradition) di Barat, Harald Motzki memetakan kepada empat metode, yaitu pertama metode analisis berbasis pada matan sebagaimana yang dilakukan oleh Ignaz Goldziher, Josepht Schacht dan Marston Speight; kedua, metode penetapan kemunculan hadis berdasarkan analisis terhadap kitab-kitab terawal koleksi hadis. Metode ini memunculkan teori argumentum e silentio yang digagas Josepht Schacth; ketiga metode analisis berbasis pada sanad, sebagaimana yang dikembangkan oleh Schacht dan GHA Juynboll dan keempat metode analisis kemunculan hadis dengan menggabungkan antara analisis sanad dan matan (isnad-cum-matn) sebagaimana ditawarkan oleh Harald Motzki. ${ }^{18}$

\section{Metode Kritik Matan Robert Marston Speight}

Dalam kajian-kajiannya Robert Marston Speight nampak lebih tertarik pada permasalahan matan hadis daripada sanad. Meskipun Speight beranggapan bahwa kajian sanad juga penting, namun realitanya tulisan-tulisan Speight lebih banyak membahas problem yang mengitari matan hadis. Lebih spesifik lagi, Speight menaruh perhatian khusus kepada dua aspek perihal matan yaitu bentukbentuk retorika matan (rethorical formula) dan perbedaan redaksi matan.

${ }^{17}$ Lihat R. Marston Speight, "The Will of Sa`d b. Abī Waqqās: The Growth of Tradition," 1973, 249-267.

18 Harald Motzki, "Dating Muslim Traditions: A Survey," 2005, 205. Pembahasan mengenai pemetaan kajian hadi di Barat dapat dilihat lebih lanjut pada artikel Ulummudin, "Pemetaan Penelitian Orientalis terhadap Hadis Menurut Harald Motzki," al-Bukhari, vol, 3, no 1, 2020, 86-104. 
Penelitiannya terhadap matan yang terdapat dalam Musnad al-Tayälisi, mengantarkan Speight pada kesimpulan menarik. Bentuk retorika matan hadis menurutnya dapat dikelompokkan ke dalam tiga tipe, yaitu declaratory formula, imperative formula dan narrative formula. Yang dimakud dengan formula deklaratif adalah matan yang berisi ucapan Nabi dalam bentuk penegasan sederhana, seperti pendefinisian konsep tertentu, statemen perbandingan, perumpamaan dan semacamnya. Sedangkan yang dimaksud dengan formula imperatif adalah matan yang berisi pernyataan yang mengandung perintah, anjuran atau larangan. Sementara itu formula naratif adalah matan yang berisi cerita mengenai tindakan atau peristiwa yang terkait dengan kehidupan Nabi atau generasi awal Islam yang dianggap penting untuk menjadi teladan umat Islam. ${ }^{19}$ Tiga bentuk retorika ini disamping memberi gambaran pola dan formula yang beragam dalam penyajian matan hadis dalam kitab-kitab hadis, juga menurut Speight memberi indikasi bahwa matan-matan yang terkumpul dalam kitab tersebut merupakan hasil dari proses panjang transmisi secara lisan. ${ }^{20}$

Selain bentuk retorika matan, keberadaan matan yang redaksinya bervariasi juga menarik perhatian Speight. Secara umum, kajian R. Marston Speight terhadap fenomena matan beragam versi dapat dikelompokkan ke dalam dua aspek; Pertama, analisis tipologi perbedaan redaksi matan, dan kedua, analisis keotentikan historis matan hadis yang beragam versi.

Terkait dengan yang pertama, Speight mangamati adanya pola-pola tertentu pada fenomena matan-matan hadis yang diriwayatkan secara berbeda. Ia menyimpulkan bahwa bentuk-bentuk perbedaan redaksi matan yang dapat dijumpai dalam kitab-kitab hadis induk, dapat dikelompokkan ke dalam tiga tipologi ${ }^{21}$, yaitu:

[1] Merekam ulang (Recording).

Tipe pertama hasil pengamatan Speight terhadap teks-teks hadis yang membicarakan kasus yang sama namun diungkapkan dengan bentuk redaksi yang berbeda adalah pola perekaman ulang. Teks hadis diungkapkan kembali dengan menggunakan kata-kata sinonim, pernyataan-pernyataan yang mirip atau dengan menggunakan bentuk kata kerja yang berbeda, namun struktur kalimatnya tetap sama dan tetap utuh. Kebanyakan, tipe pertama seperti ini berupa hadis-hadis penegasan sederhana atau kalimat perintah yang diutarakan oleh Nabi. Dalam pola pertama seperti ini, uraian-uraian rinci dalam bentuk pendetilan tidak

${ }^{19}$ R. Marston Speight, "Oral Traditions of the Prophet Muhammad: A Formulaic Approach," Oral Tradition, IV/1-2, 1989, 30-35.

${ }^{20}$ R. Marston Speight, "Oral Traditions of the Prophet Muhammad: A Formulaic Approach," 1989, 36.

${ }^{21}$ Lihat R. Marston Speight, “A Look at Varian Readings in the Hadith,” 2000, 170-174. 
ditemukan. Perbedaan yang ditemukan hanya perbedaan bentuk namun struktur kalimat dan maknanya tetap sama.

[2] Merubah rincian atau struktur kalimat (Change of detail or structure).

Berbeda dengan pola pertama yang tidak merubah komposisi struktur kalimat dalam matan hadis, pola kedua yang diidentifikasi Speight adalah pola yang menyebabkan perubahan struktur kalimat. Perubahan tersebut bisa jadi sebab adanya penambahan komponen atau pengurangan. Pada tipe kedua ini, uraian-uraian rinci yang terdapat dalam teks mengalami perubahan atau penambahan, sehingga kadang menyebabkan perubahan struktur teks matan. Versi redaksi matan yang tersuguhkan pada kategori pola kedua ini menunjukkan perbedaan nyata antara satu matan dengan matan lainnya. Di antara model perbedaan redaksi kategori kedua ini adalah penggabungan beberapa teks sehingga menjadi teks yang lebih panjang; adanya tambahan komponen uraian rinci yang berfungsi sebagai penafsir atas teks matan yang lebih pendek; tambahan komponen kalimat yang berfungsi menjelaskan makna kosa kata atau frasa; elaborasi terhadap ungkapan verbal; dan juga meringkas kalimat matan yang asalnya panjang atau detil.

[3] Gabungan antara tipe pertama dan kedua.

Speight mengamati bahwa selain dua pola di atas, kadang juga ditemukan pola ragam versi redaksi matan yang timbul akibat adanya fenomena gabungan antara dua pola yang telah diterangkan sebelumnya, yaitu gabungan antara tipe pertama dan tipe kedua. Dalam kasus seperti ini, di samping pada body text (teks matan utama) ditemukan kata atau pernyataan yang mirip, juga ditemukan perubahan dan penambahan uraian-uraian yang lebih detail dalam teks tersebut. Dengan demikian pola ketiga ini disamping merubah struktur kalimat juga dibarengi dengan perubahan penggunaan kosa kata.

Tiga tipe perbedaan redaksi matan ini juga dijadikan dasar oleh Speight untuk mengambil kesimpulan bahwa fenomena tersebut adalah refleksi dari proses transmisi hadis secara lisan (oral performance), bukan variasi yang muncul akibat penulisan (scribal variation). ${ }^{22}$ Dengan kata lain, Speight menegaskan bahwa transmisi hadis pada masa periwayatan yang kemudian terekam dalam kitab-kitab hadis yang ditulis pada tiga abad pertama hijriah adalah transmisi yang berbasis pada dominasi aktifitas lisan bukan tulisan.

Aspek kedua dari fenomena perbedaan redaksi matan yang menjadi perhatian Speight adalah sisi historisitas kemunculan dan perkembangan variannya. Metode yang digunakan Speight untuk melakukan analisis keotentikan historis keragaman versi matan adalah metode form analysis. Metode ini dalam kajian keagamaan di Barat dikembangkan dan diaplikasikan dalam studi Bible.

22 R. Marston Speight, “A Look at Varian Readings in the Hadith,” 2000, 175. 
Teknisnya adalah dengan cara membandingkan manuskrip-manuskrip Bible yang seringkali menampilkan redaksi yang berbeda-beda. Menurut Harald Motzki pada tahun 1970-an metode form analysis ini mulai marak diaplikasikan dalam Islamic Studies di Barat. ${ }^{23}$ Speight sendiri mencoba menggunakan metode ini dalam kajian hadis. Dia berupaya mengkonstruk ulang urutan kronologi perkembangan suatu matan hadis dengan cara membandingkan ragam redaksi matan yang ada yang membahas satu tema namun beragam bentuk redaksinya. ${ }^{24}$ Speight berkeyakinan bahwa ragam redaksi matan tersebut dapat ditelusuri mana yang lebih awal muncul dan mana yang hadir belakangan. Analisis Speight ini didasari pada asumsi bahwa semua variant teks matan hadis yang beragam, pada awalnya adalah oral tradition (kabar yang diinformasikan melalui lisan) sebelum menjadi catatan tertulis yang terkompilasi dalam kitab-kitab hadis, sehingga perubahan redaksi baik dalam bentuk perubahan kata, penambahan kalimat atau perubahan struktur kalimat sangat mungkin terjadi.

Metode form analysis yang ditawarkan Speight secara umum meliputi dua langkah besar. Pertama adalah pengumpulan data melalui proses identifikasi dan pengumpulan teks-teks hadis yang semakna dari kitab-kitab hadis induk. Kedua adalah proses analisis dengan penekanan pada pengamatan terhadap kriteria bentuk teks (formal criteria); seperti panjang-pendeknya teks, penggunaan kutipan langsung (direct quotation; kata ganti orang pertama) atau kutipan tidak langsung (indirect quotation; kata ganti orang ketiga), tingkat pendeskripsian apakah global atau rinci (level of description), dan juga kesatuan serta kepaduan teks (unity and coherence of the text). ${ }^{25}$

Salah satu target yang menjadi tujuan utama dalam proses analisis dengan metode form analysis adalah untuk menetapkan masa kemunculan suatu teks dan juga urutan kronologis perkembangannya. Untuk keperluan ini Speight menetapkan suatu kaidah, yaitu ketiadaan uraian yang detail pada teks dan juga penggunaan kutipan tidak langsung, secara umum dianggap sebagai indikator bahwa teks tersebut muncul lebih awal. Sedangkan teks yang panjang, berisi uraian

${ }^{23}$ Harald Motzki, "Hadīth: Origins and Developments", dalam Harald Motzki (ed.), The Formation of the Classical Islamic World: Hadith. (Aldershot, Hant: Ashgate, 2004), xivi.

${ }^{24}$ R. Marston Speight, "The Will of Sa'd b. Abī Waqqās: The Growth of Tradition," 1973, 249-67. Lihat juga R. Marston Speight, "A Look at Varian Readings in the Hadith,” 2000, $169-79$.

${ }^{25}$ Lihat penyimpulan David S Powers dalam "The Will of Sa'd b. Abī Waqqās: a Reassessment," Studia Islamica, vol. LVIII, 1989, 39. 
yang detail dan adanya kutipan langsung merupakan indikator bahwa teks tersebut muncul belakangan. ${ }^{26}$

Secara prosedural, metode analisis yang dilakukan Speight dapat disederhanakan ke dalam empat langkah metodis sebagai berikut ${ }^{27}:$ [1] mengumpulkan hadis-hadis yang semakna; [2] menyusunnya sesuai dengan urutan kompleksitas; [3] analisis bentuk (form) dan isi (content), dan [4] mengklasifikasi dan menyimpulkan kronologi kemunculannya.

Langkah pertama adalah mengumpulkan hadis-hadis yang membicarakan satu kasus yang sama namun redaksinya beragam. Sudah barang tentu, sumber utama dalam proses pencarian ini adalah kitab-kitab hadis induk yang ditulis pada masa periwayatan. Langkah kedua adalah menyusun teks-teks hadis yang sudah terkumpul berdasarkan kompleksitasnya. Teks hadis yang pendek dan sederhana diletakkan di bagian awal, sedangkan teks hadis yang panjang dan lebih kompleks diletakkan setelahnya secara urut.

Langkah ketiga adalah menganalisis masing-masing teks matan hadis dengan mempertimbangkan tiga aspek berikut ini: [a] Variasi penggunaan dan perubahan kosa kata dalam teks-teks matan hadis yang redaksinya beragam. Hal ini perlu dipertimbangkan untuk mengidentifikasi tingkat konsistensi atau dinamika variasi penggunaan kosa kata dalam matan hadis; [b] Hal kedua yang dipertimbangkan ketika menganalisis teks matan hadis adalah mempertimbangkan tingkat kepaduan internal elemen-elemen yang ada dalam teks tersebut. Sebuah matan hadis kadang tersusun dari satu elemen kalimat pokok saja, namun dalam versi lain kadang ia juga mempunayi elemen-elemen kalimat tambahan. Elemen-elemen yang membentuk kalimat pokok dan kalimat pendukung tersebut kadang tersusun secara padu, jelas dan mudah dipahami, namun pada versi lain hubungan antar elemen tersebut kadang ambigu dan perlu usaha ekstra untuk memahami kepaduannya. Speight mempunyai kecendrungan untuk menetapkan bahwa matan yang elemen kalimatnya tersusun secara terpadu mucul belakangan dibanding dengan matan yang rumit hubungan antar elemennya; [c] Bagian terakhir yang perlu dipertimbangkan adalah tingkat perkembangan terbentuknya teks (degree of development). Teks hadis yang dikumpulkan sudah barang tentu tidak sama bentuk susunan kalimatnya, sehingga perlu upaya pengidentifikasian tahap perkembangan terbentuknya teks yang beragam tersebut. Untuk keperluan tersebut Speight menggunakan dua istilah kunci, yaitu vertical development dan horizontal development. Yang dimaksud dengan

${ }^{26}$ Lihat penyimpulan David S Powers dalam "The Will of Sa'd b. Abī Waqqās: a Reassessment," 1989, 39.

${ }^{27}$ Langkah-langkah tersebut adalah hasil pengamatan Harald Motzki yang ditulis dalam "Hadīth: Origins and Developments," 2004, xivi. Penulis memberikan tambahan-tambahan seperlunya untuk memperjelas maksud masing-masing langkah tersebut. 
vertical development adalah adanya fakta berupa perbedaan-perbedaan kecil yang ditemukan dalam beberapa versi teks matan hadis, namun secara umum versiversi tersebut mempunyai struktur dan konten kalimat yang sama. Sedangkan yang dimaksud dengan horizontal development adalah apabila ditemukan elemenelemen baru yang dikombinasikan dengan komponen teks yang lebih awal muncul, atau elemen lama tetap ada, namun disusun ulang dengan urutan yang berbeda sehingga menampilkan struktur susunan kalimat yang berbeda serta kontennya juga bervariasi.

Langkah keempat dalam proses analisis matan beragam versi yang ditawarkan Speight adalah mengklasifikasikan secara kronologis ragam teks matan hadis dengan mempertimbangkan tiga aspek pada langkah ketiga. Dengan kata lain tiga aspek tersebut dijadikan indikasi untuk menetapkan mana yang lebih awal dan mana yang belakangan muncul dalam tahapan perkembangan teks tersebut. Tentunya penentuan kronologi kemunculan teks ini dengan mempertimbangkan kaidah umum yang ditetapkan Speight bahwa teks yang lebih panjang, detail, mengandung banyak elemen dan antar elemen terjalin secara padu muncul belakangan dibanding teks matan yang ringkas, minim penjelasan dan elemennya tidak padu.

\section{Analisis Kritis Terhadap Metode R. Marston Speight}

Metode kritik matan sebenarnya telah diformulasikan oleh para ulama muslim baik klasik maupun kontemporer. Di antara karya representatif yang mendeskripsikan konstruk metode kritik matan ahli hadis di antaranya adalah Manhaj Naqd al-Matn 'inda 'Ulamā' al-Ḥadīs karya Șalāḥ al-Dīn al-Idlibī; Juhūd al-Muḥaddisīin fì Naqd Matn al-Hadīì karya Muḥammad Ṭāhir al-Jawwābī; dan Maqāyis Naqd al-Sunnah karya al-Dumīnī.

Secara umum, di Barat metode kritik matan lebih bersifat skeptical approach, meragukan dan bahkan menggugat keotentikan matan. Metode form analysis yang dikenalkan oleh Speight adalah salah satu metode alternatif yang dikenalkan di Barat untuk menganalisis hadis, terutama hadis-hadis yang mempunyai bentuk redaksi matan yang berbeda. Terget utamanya adalah untuk melakukan rekonstruksi awal kemunculan matan hadis dan juga perkembangan bentuknya.

Apa yang dikenalkan oleh Speight bertumpu kepada teknik komparasi antara matan hadis yang tersedia. Proses dan prosedur komparasi (muqäranah) dan konfrontir data (mu'aradah) seperti ini di kalangan ahli hadis klasik dikenal dengan istilah al-i'tibär, yaitu mencari dan mempertimbangkan jalur-jalur sanad lain beserta ragam matannya untuk mendapatkan gambaran yang lebih komprehensip mengenai hadis yang sedang diteliti. Jalur-jalur sanad lain beserta matannya diistilahkan dengan al-syähid dan al-täbi. 
Meski ada titik persinggungan antara metode form analysis dengan metode al-i'tibär di kalangan ahli hadis, namun terdapat beberapa perbedaan yang signifikan di antara keduanya. Setidaknya terdapat tiga area yang menjadi penekanan dalam metode kritik matan yang digagas oleh Speight ini, yaitu matan beragam versi dijadikan bukti oral transmission, penyebab matan beragam versi adalah kontribusi kreatif perawi, dan metode form analysis adalah metode yang oleh Speight dianggap representatif untuk mendeteksi perkembangan bentuk redaksi matan tersebut. Berikut ini beberapa catatan dan kritikan terhadap metode kritik matan yang dikembangkan oleh Speight terutama metode form analysis.

Pertama. Dalam pandangan Speight data-data matan hadis yang menampilkan ragam redaksi yang berbeda-beda dijadikan dasar untuk menyimpulkan bahwa proses transmisi hadis pada masa awal Islam, abad pertama, kedua dan ketiga adalah transmisi melalui lisan (oral transmission) bukan tansmisi melalui tulisan.

Tidak dapat dipungkari bahwa periwayatan melalui tuturan lisan pada masa awal Islam memang terjadi, namun anggapan bahwa pada masa awal Islam tidak ada aktifitas pencatatan hadis sama sekali adalah anggapan yang tidak tepat. Imtiyaz Ahmad dalam The Significance of Sunna and Hadith and Their Early Documentation mengemukakan beberapa data bahwa pada masa Nabi, aktifitas pencatatan hadis sudah berlangsung. Hal ini dibuktikan dengan keberadaan catatan-catatan resmi terkait dengan masalah hukum dan pengelolaan keuangan yang dikirim oleh Nabi kepada beberapa sahabat yang mendapatkan tugas di beberapa daerah di luar Madinah. Nabi juga tercatat mengirimkan beberapa surat kepada beberapa penguasa daerah lain pada masa itu. Selain itu para sahabat juga mempunyai catatan-catatan pribadi (șhiffah) yang merekam ucapan-ucapan Nabi. ${ }^{28}$ Penjelasan tersebut memberikan gambaran bahwa dominasi transmisi hadis pada masa awal Islam memang berbasis lisan, namun periwayatan dengan tulisan juga dilakukan. Data-data mengenai penulisan hadis di awal Islam juga dikemukakan oleh Muhammad Mustafa A'zami dalam disertasinya Studies in Early Hadith Literature. ${ }^{29}$

Kedua. Dalam pandangan Speight, keberadaan hadis yang redaksi matannya beragam memunculkan keraguan atas keotentikannya. Apakah matan tersebut memang bersumber pada masa Nabi atau terbentuk pada masa-masa berikutnya. Speight cenderung skeptis dan setuju dengan kesimpulan kedua bahwa orang-orang yang hidup jauh setelah Nabi-lah yang menyusun redaksi tersebut, dan kemudian dikembangkan secara kreatif oleh orang-orang setelahnya. Dengan kata lain, perbedaan-perbedaan versi yang terdapat dalam matan hadis dari mulai yang simpel sampai yang kompleks dijadikan indikasi adanya evolusi

28 Imtiyaz Ahmad, The Significance of Sunna and Hadith and Their Early Documentation (Disertasi, University of Edinburg, 1974), 307-455.

29 Lihat Muhammad Mustafa A'zami, Studies in Early Hadith Literature (Indianapolis: American Truth Publications, 1978). 
pembentukan struktur kalimat matan yang -karena dipengaruhi situasi kehidupannya (life situations)- dilakukan oleh para perawi.

Pandangan Speight seperti ini nampak tidak mempertimbangkan konteks natural periwayatan pada masa awal Islam. Ia menafikan fenomena riwajyah bi alma'nā yang memang diperkenalkan pada masa awal-awal periwayatan. Ketika transmisi dilakukan melalui lisan -terlebih lagi jika hadisnya berbentuk ceritamaka sangat dimungkinkan perbedaan redaksi terjadi. Di antara penyebabnya adalah sebagian perawi menggunakan kata sinonim, atau menceritakan kisah dengan narasinya sendiri, sehingga terjadi perbedaan redaksi, namun mereka tetap menjaga supaya substansinya tetap sama. Data-data yang ada mengindikasikan bahwa pada masa awal-awal periwayatan, model penyampaian hadis tanpa harus setia dengan redaksi awalnya diperkenalkan asalkan tidak mereduksi substansinya. Selain riwāyah bi al-ma'nā, perbedaan redaksi juga tidak menutup kemungkinan disebabkan karena terjadinya kesalahan periwayatan (al-khata' fi al-riwwajyab). Perbedaan redaksi yang disebabkan kesalahan periwayatan seperti ini -baik dalam bentuk kesalahan penggunaan kosa kata, penambahan elemen, atau perbedaan model periwayatan- diistilahkan oleh ahli hadis dengan syäz, atau 'illat, dan sudah barang tentu tidak diterima sebagai informasi yang valid. Istilah-istilah teknis lain yang memberi informasi terjadinya kesalahan periwayatan dalam sebuah matan yang biasa digunakan oleh ahli hadis di antaranya adalah al-idräj, al-zawä̀id, almunkar, al-maqlüb, dan al-mukbtalat.

Mengenai masalah ini Iftikhar Zaman lebih jauh menjelaskan setidaknya ada dua faktor penyebab munculnya ragam bentuk matan dan timbulnya ragam kuantitas elemen struktur kalimat pada matan hadis, yang oleh Speight ditengarai sebagai fenomena evolutif matan. Dua faktor yang dimaksud Zaman adalah terjadinya peringkasan periwayatan (abbreviation) dan terjadinya kesalahan periwayatan (mistakes in transmission). Yang pertama terjadi secara sengaja (intentional variations) karena memang ada keperluan untuk memilih bagian yang dibutuhkan, sedangkan yang kedua bersifat tidak sengaja (unintentional variations). ${ }^{30}$ Dua faktor inilah yang menyebabkan terjadinya perbedaan redaksi matan.

Dengan demikian, perbedaan redaksi matan tidak bisa selalu dibaca sebagai bentuk pemalsuan dan kreatifitas para perawi yang didasari kepentingankepentingan tertentu. Variasi redaksi matan an sich bukanlah dalil untuk menetapkan reliabilitas atau tidaknya suatu hadis, dan ia dengan sendirinya juga bukan alat bukti untuk menentukan historisitis kejadian yang diceritakan dalam hadis. ${ }^{31}$

${ }^{30}$ Iftikhar Zaman, The Evolution of $A$ Hadith: Transmission, Growth and the Science of Rijal in a Hadith of Sa'id b. Abi Waqqas, (Disertasi, University of Chicago, 1991), 21, 23.

31 Iftikhar Zaman, The Evolution of A Hadith: Transmission, Growth and the Science of Rijal in a Hadith of Sa'id b. Abi Waqqas, 1991, 49. 
Ketiga. Salah satu istilah kunci yang digunakan Speight untuk menggambarkan terjadinya variasi redaksi matan adalah vertical development, yaitu terjadinya perbedaan-perbedaan kecil yang ada di dalam beberapa versi, namun versi-versi itu secara umum struktur dan kandungannya masih sama. ${ }^{32}$ Perbedaan redaksi bentuk seperti ini di satu sisi dijadikan dasar oleh Speight untuk bersikap skeptis terhadap keotentikan matan hadis, dan di sisi lain dijadikan instrumen untuk melacak terjadinya kronologi perubahan redaksi matan.

Perbedaan-perbedaan sederhana seperti penggunaan sinonim, atau penambahan penjelas terhadap suatu kata atau kalimat adalah aktifitas tutur yang normal, saat seseorang menyampaikan ulang informasi yang ia peroleh sebelumnya. Perubahan kosa kata atau penambahan kalimat penjelas seperti ini biasanya dilakukan oleh informan dengan tujuan supaya pesan informasi yang diungkapkan dapat tersampaikan dengan baik dan mudah dipahami oleh lawan bicaranya. Tindakan merubah bentuk kata atau kalimat seperti ini ditolelir dalam aktifitas komunikasi asalkan tidak sampai mereduksi makna. Dalam periwayatan hadis fenomena seperti ini disebut dengan al-riwayyah bi al-ma'nā. Para ahli hadis generasi awal melegalkan model periwayatan seperti ini, meskipun informasi dalam satu elemen matan dikemukakan dengan cara yang pelbagai, namun pesan utamanya tetap sama dan terjaga substansinya. Apa yang disebut oleh Speight sebagai vertical development sebenarnya dapat dibaca sebagai bentuk al-riwajyah bi alma'nā seperti ini, dan tidak harus dicurigai sebagai bentuk kreatifitas perawi yang didasari kepentingan-kepentingan negatif tertentu.

Memang benar, fenomena vertical development dalam beberapa kasus kadang menimbukan problem yang tidak dapat dianggap sebagai bentuk periwayatan $b i$ al-ma'nā, yaitu saat perubahan kata atau kalimat yang disajikan oleh perawi menyebabkan informasi yang ia sampaikan bertentangan secara diametral dengan informasi yang disampaikan oleh perawi lainnya. Keberatan Speight terhadap fenomena ini cukup mendasar. Namun kasus seperti ini sebenarnya sudah diantisipasi oleh para ahli hadis dengan membuka kemungkinan adanya al-khata' fi al-riwajyah (kesalahan periwayatan), bahkan oleh perawi yang dinilai siqah sekalipun. Untuk mengidentifikasi kesalahan periwayatan sudah barang tentu lengkah metodologis yang harus dilakukan adalah dengan mengkomparasikan perbedaan redaksi tersebut beserta jalur sanad yang menopangnya. Dalam menganalisis masalah ini Speight tidak mempertimbangkan kemungkinan ini. Ia tidak melihat keragaman kluster jalur sanad yang mendukung masing-masing ragam redaksi matan. Dia juga tidak mempertimbangkan kualitas masing-masing jalur sanad tersebut. Padahal jalur sanad yang beragam tersebut tidak selalu bernilai sama, dan hal tersebut ada kaitannya dengan keragaman matan yang muncul. Jalur sanad yang menghadirkan matan yang bertentangan dengan jalur

32 Iftikhar Zaman, The Evolution of A Hadith: Transmission, Growth and the Science of Rijal in a Hadith of Sa'id b. Abi Waqqas, 1991, 252. 
sanad yang lebih kuat dan lebih banyak dianggap periwayatan yang salah dan tidak bisa diterima. Sehingga masalah informasi kontradiktif karena perbedaan kosa kata atau kalimat seperti ini -yang oleh Speight dikategorikan sebagai bagian dari bentuk vertical development- bagi muhaddis̈un, dapat terselesaikan dengan menetapkan bahwa terjadi kesalahan periwayatan yang dilakukan pada sebagian informan.

Keempat. Di antara tujuan utama penggunaan form analysis dalam analisis matan beragam versi adalah untuk menetapkan masa kemunculan teks matan hadis yang diteliti dan juga urutan kronologis perkembangannya. Speight meskipun tidak secara eksplisit- menetapkan kaidah yang menjadi acuan dalam proses analisisnya. Kaidah tersebut adalah, ketiadaan uraian yang detail pada teks dan juga penggunaan kutipan tidak langsung, secara umum dianggap sebagai indikator bahwa teks tersebut muncul lebih awal. Sedangkan teks yang panjang, berisi uraian yang detail dan adanya kutipan langsung merupakan indikator bahwa teks tersebut muncul belakangan. ${ }^{33}$ Untuk menggambarkan adanya dinamika penambahan elemen dalam struktur kalimat matan hadis seperti ini, Speight menyebutnya dengan istilah horizontal development.

Metode ini berasumsi bahwa teks yang lebih pendek selalu muncul lebih awal daripada teks yang lebih panjang. Asumsi seperti ini sebenarnya tidak mempunyai dasar yang kuat baik dalam periwayatan hadis maupun dalam proses transmisi informasi secara umum. Pandangan seperti ini mengabaikan fakta kondisi spesifik yang kadang mengiringi tuturan seorang informan. Selain itu pandangan ini juga mengabaikan probabilitas maksud dan tujuan seorang informan yang beragam saat menyampaikan suatu informasi. Kadang seorang informan [1] menyampaikan suatu informasi secara lengkap (full version); namun kadang pula [2] ia meringkas atau memilih poin yang memang perlu untuk diinformasikan saat itu (truncated version; ikhtisāar). Sehingga teks yang pendek bisa jadi merupakan ringkasan dari teks yang lebih lengkap dan panjang yang beredar lebih awal.

Faktor al-khata' fi al-riwāyah (kesalahan periwayatan) memang mungkin terjadi dalam fenomena yang disebut Speight dengan horizontal development ini. Penambahan elemen dalam struktur kalimat matan bisa jadi adalah sisipan (idräj) dari perawi. Sisipan seperti ini dalam kajian ahli hadis tidak selalu diterima, dalam kasus-kasus tertentu sisipan tersebut dianggap sebagai kesalahan transmisi yang tidak dapat diterima. Tentunya, untuk sampai pada kesimpulan seperti ini metode komparasi dilakukan oleh ahli hadis, bukan hanya antara matan yang beragam redaksi, namun juga antara kluster jalur sanad yang menopang matan-matan tersebut, untuk mengidentifikasi para perawi yang bermasalah.

${ }^{33}$ Lihat penyimpulan David S Powers dalam "The Will of Sa'd b. Abī Waqqās: a Reassessment," 1989, 39. 
Kelima. Nampak sangat jelas bahwa metode form analysis yang dikembangkan oleh Speight hanya berbasis kepada analisis matan, tanpa mempertimbangkan sedikitpun keragaman sanad. Speight sendiri mengatakan "not because they are considered to be unimportant, but simply because a form analysis must be concerned primarily with the structure of the matn [text]" ${ }^{34}$ Penetapan kemunculan hadis berbasis matan seperti ini sebenarnya sudah digagas oleh Joseph Schacht. Apa yang dilakukan oleh Speight adalah pemformulasian dan pengembangan gagasan Schacht tersebut. Dating traditions (mencari masa kemunculan hadis) dengan menggunakan metode seperti ini sebenarnya telah menuai kritikan dari beberapa sarjana Barat sendiri. Harald Motzki misalnya menyatakan bahwa premis dan metode form analysis tidak dapat memberikan hasil yang akurat. Analisis matan dapat memberi kontribusi dalam menetapkan masa kemunculan hadis dengan baik apabila ia dikombinasikan dengan metode-metode lainnya. ${ }^{35}$ Motzki menegaskan bahwa prinsip dan premis metode ini tidak cukup teliti (not sufficiently sophisticated) sehingga menimbulkan keraguan mengenai tingkat validitas prinsipprinsip dan premis-premis pada metode tersebut. Secara umum muncul kebimbangan, apa mungkin menetapkan kemunculan suatu hadis secara presisi hanya berdasarkan pada analisis matan saja. ${ }^{36}$ Senada dengan Motzki, Iftikhar Zaman juga menegaskan bahwa penelitian hadis dengan metode form analysis tidak dapat mencapai hasil yang maksimal tanpa memperhitungkan secara utuh jaringan dan kluster sanad yang menopangnya. Menelusuri kemunculan variasi redaksi matan dengan cara mengaitkannya dengan ragam kluster jalur sanadnya jauh lebih logis bila dibanding menentukan kemunculan variasi redaksi tersebut hanya dengan mengacu pada situasi abstrak yang diperoleh atas dasar perkiraan dari data teks matan saja. ${ }^{37}$ Lebih jauh lagi Iftikhar Zaman menolak pihak yang menganggap bahwa nama-nama perawi dalam sanad yang menopang matan hadis beragam versi tersebut adalah nama-nama yang secara random dicomot karena alasan prestise tertentu lalu ditempelkan pada satu matan hadis. Zaman menegaskan bahwa pandangan seperti ini tidak tepat, sebab jika demikan adanya maka tidak akan dijumpai data yang menampilkan pola konsisten antara perbedaan redaksi matan dengan kluster-kluster jalur sanad tertentu yang menopangnya. ${ }^{38}$ Banyak data menunjukkan bahwa matan yang menampilkan redaksi pendek secara konsisten selalu melalui kluster jalur sanad tertentu, sedangkan redaksi matan yang panjang dapat dipastikan melalui kluster sanad lain yang berbeda dengan jalur

${ }^{34}$ R. Marston Speight, "The Will of Sa'd b. Abī Waqqās: The Growth of Tradition," 1973, 249-250.

35 Harald Motzki, "Dating Muslim Traditions: A Survey," 2005, 211-214.

${ }^{36}$ Harald Motzki, "Hadīth: Origins and Developments", 2004, xlvii.

${ }^{37}$ Iftikhar Zaman, The Evolution of A Hadith: Transmission, Growth and the Science of Rijal in a Hadith of Sa'id b. Abi Waqqas, 1991, 33.

38 Iftikhar Zaman, The Evolution of A Hadith: Transmission, Growth and the Science of Rijal in a Hadith of Sa'id b. Abi Waqqas, 1991, 194. 
sanad pertama juga dengan intensitas yang konsisten. Penjelasan Iftikhar Zaman ini menegaskan bahwa untuk meneliti kemunculan hadis, dua komponen penting dalam hadis yaitu matan dan sanad harus secara berbarengan diperhatikan, tidak hanya satu komponen saja sebagaimana yang dilakukan oleh Speight. Atas dasar inilah maka tidak berlebihan jika Ali Kuzudişli mengatakan "in the works of Speight, the connections between hadith text and their narrators, was not studied in any systematic methode" Dalam tulisan-tulisan Speight, hubungan antara teks matan hadis dengan para perawinya tidak dikaji dengan menggunakan metode yang sistemik. ${ }^{39}$

Keenam. Selain hal-hal di atas, terdapat satu lagi catatan terhadap metode form analysis yang dikembangkan Speight. Metode analisis ini tidak mempertimbangkan metode penyusunan matan hadis dalam kitab-kitab hadis primer. Setiap kitab mempunyai metode penyusunan dan penyeleksian hadis yang khas, dan secara implisit menerangkan problem-problem matan beragam versi dan juga permasalahan dalam sanadnya (al-șinä'ah al-hadïsiyyah wa al-isnädiyyah). Di dalam Kitab al-Sahih karya Imam Muslim (w. 261 H) misalnya, Imam Muslim mempunyai metode khas dalam penyajian hadis berdasarkan bab-bab tertentu. Secara umum, dalam satu bab beliau menghadirkan ragam versi matan dan juga ragam jalur sanad. Beliau memulai dengan jalur yang diriwayatkan para perawi $\dot{s} i q a h$, kemudian diikuti dengan jalur sanad yang diriwayatkan para perawi yang kualitasnya di bawahnya yang kadang mengandung masalah (illat). Namun Imam Muslim tidak menerangkan masalah (iillat) tersebut secara eksplisit. Beliau sebagaimana para ahli hadis generasi awal- menerangkan permasalahan illat tersebut secara implisit (istiträ $\left.d^{a t}\right) .{ }^{40}$ Penyajian hadis seperti ini tentunya menunjukkan adanya keterkaitan yang erat antara perbedaan matan dengan keragaman sanad yang menopangnya, terlebih lagi jika dalam matannya terdapat perbedaan yang problematik maka dapat dipastikan ada masalah dalam jalur sanadnya.

Dalam tradisi periwayatan hadis generasi awal terdapat satu kaedah "man asnadak fa qad ahālak" (barangsiapa meriwayatkan suatu matan dilengkapi dengan sanadnya, maka dia telah memberi isyarat kepadamu supaya kamu mengamati kualitasnya). Tidak adanya keterangan eksplisit mengenai status suatu hadis atau perawi pada generasi awal adalah hal yang dimaklumi bersama, sebab para ahli ilmu hadis masa itu apabila disebutkan satu jalur sanad tertentu maka dia sudah

${ }^{39}$ Ali Kuzudişli, "The Overview to Structural Forms of The Narrations about Bāla A’rabiyyun fì al-Masjid," Gümüşhane Üniversitesi Ilabiyat Fakültesi Dergisi, vol 4, issue 7, 2015, 70.

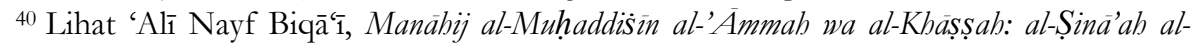
Hadïsiyyah (Beirut: Dār al-Basyā̄ir al-Islāmiyyah, 2003), 119-120, dan Ḥamzah 'Abd Allāh alMalībārī, 'Abqariyyat al-Imām Muslim fì Tartìb Ahạdïsi Musnadih al-Ṣahịh: Dirāsah Tahlïliyyah (Riyāụ: Dār Ibn Hazm, 1997). 
terbayang kualitasnya, tanpa harus diterangkan secara detail dan eksplisit mengenai masalah itu.

Hal-hal seperti ini tidak menjadi perhatian dan pertimbangan Speight dalam menganalisis keragaman versi matan. Semua jalur sanad baginya dianggap sama dan perbedaan matan yang ada hanya dijadikan indikator adanya kreatifitas dan interfensi kontribusi para perawi dalam terbentuknya sebuah teks. Speight tidak meneliti lebih lanjut kaitan keragaman jalur sanad dengan keragaman matan yang ada, dan juga tidak mempertimbangkan metode penyusunan yang dilakukan oleh para penyusun kitab hadis.

\section{Kesimpulan}

Di Barat, otoritas dan otentisitas hadis sebagai sumber utama untuk merekonstruksi sejarah Islam generasi awal (masa Nabi dan sahabat) menjadi perdebatan dan cenderung dipertanyakan. Tingkat keraguan akademisi Barat terhadap keotentikan hadis memang tidak seragam. Namun secara umum, skeptical approach menjadi warna utama kajian mereka. Kecenderungan serupa juga terlihat dalam tulisan-tulisan Robert Marston Speight.

Dalam kajian-kajiannya, Speight lebih minat kepada kajian kritik matan dibanding kritik sanad, terutama mengenai problem matan beragam versi (ta'addud al-riwajāat/variant version). Ia berpandangan bahwa proses transmisi hadis pada generasi awal Islam bertumpu pada transmisi oral, yang sering mengalami penyisipan, penghilangan, distorsi, kombinasi, dan penambahan dalam proses periwayatannya, sehingga struktur kalimat dan retorika dalam matan hadis tidak bisa dianggap sebagai produk murni satu generasi. Bagi Speight keberadaan matan yang mempunyai redaksi beragam dianggap sebagai indikasi adanya distorsi, sehingga otentisitasnya perlu dikritisi.

Selain itu Speight juga menawarkan metode untuk menganalisis dan mengkritisi matan beragam versi. Metode yang ia tawarkan sebenarnya bentuk pengembangan metode yang sudah dikenalkan oleh para pengkaji hadis di Barat sebelumnya, khususnya Joseph Schacht. Cara kerja metode yang ia sebut dengan form analysis tersebut bertumpu pada komparasi antar redaksi matan untuk mencari perbedaan bentuknya, kemudian menetapkan awal mula kemunculannya dan juga kronologi perkembangannya.

Pandangan-pandangan Speight mendapat banyak kritikan dari para akademisi baik di Barat maupun di Timur, seperti Harald Motzki, David S. Powers, Iftikhar Zaman dan juga Ali Kuzudişli. Berdasarkan analisis kritis yang sudah dilakukan dapat disimpulkan bahwa kelemahan pandangan Speight termasuk metode form analysis yang ia tawaran terletak pada lemahnya asumsiasumsi yang diyakini karena dibangun di atas data-data yang tidak kuat dan tidak akurat. Selain itu struktur metode yang ia tawarkan juga tidak komprehensif karena hanya bertumpu pada kritik matan saja tanpa memperhatikan keterkaitannya dengan kritik sanad. 


\section{Bibliografi}

A'zami, Muhammad Mustafa. Studies in Early Hadith Literature. Indianapolis: American Truth Publications, 1978.

Ahmad, Imtiyaz. The Significance of Sunna and Hadith and Their Early Documentation. Disertasi, University of Edinburg, 1974.

al-Malībārī, Hamzah 'Abd Allāh. 'Abqariyyat al-Imām Muslim fì Tartīb Ahāàìsi Musnadih al-Șahịh: Dirāsab Tahlizliyyah. Riyāḍ: Dār Ibn Hazm, 1997.

Berg, Herbert. "Competing Paradigms in the Study of Islamic Origins: Qur'an 15:89-91 and the Value of Isnad" dalam Herbert Berg (ed.), Method and Theory in the Study of Islamic Origins. Leiden: Brill, 2003.

Berg, Herbert. The Development of Exegesis in Early Islam. Surrey: Curzon Press, 2000.

Beyanuni, Fethuddin. Madkhal ilā al-Istisyrāa al-Mu'āsirir wa Tlm al-Hadīs. Riyāḍ: Jāmi’ah al-Malik Sa’ūd Press, 1432.

Biqā̄î̀, 'Alī Nayf. Manāhij al-Muhaddisiñn al-'Āmmah wa al-Khäṣsab: al-Sināah alHadïsiyyah. Beirut: Dār al-Basyā ir al-Islāmiyyah, 2003.

Bishop, Eric F. F. "Form Criticsm and The Forty-Two Tradition of an-Nawawi." The Moslem World, vol 30, 1940: 253-261. [doi: https://doi.org/10.1111/j.1478-1913.1940.tb00451.x]

Denffer, Ahmad von. Literature on Hadith in European Languages: A Bibliographi. Leicester, UK: The Islamic Foundation, 1981.Gibb, H.A.R. "The Origins of Muhammadan Jurisprudence by Joseph Schacht (Notice of Books)." Journal of Comparative Legislation and International Law, vol. 33, 1951: 113114.

Idlibī, al- Șalāḥ al-Dīn ibn Aḥmad. Manbaj Naqd al-Matn 'inda Ulamā' al-Hadìs. Beirut: Dār al-Afāq al-Jadīdah, 1983.

Juynboll, G.H.A. Muslim Tradition: Studies in Chronology, Provenance and Authorship of Early Hadith. Cambridge: Cambridge University Press,1983.

Kister, M.J. "Pare Your Nails: a Study of an Early Tradition." Journal of the Ancient Near Eastern Society of Columbia University, vol. 11, 1979: 63-70.

Kuzudișli, Ali. "The Overview to Structural Forms of The Narrations about Bāla A'rabiyyun fì al-Masjid." Gümüshane Üniversitesi Ilabiyat Fakültesi Dergisi, vol 4, issue 7, 2015: 66-90. 
Motzki, Harald. "Dating Muslim Traditions: A Survey." Arabica, vol. LII, no. 2, 2005: 204-253. [doi: https://doi.org/10.1163/1570058053640349]

Motzki, Harald. “Quo Vadis Hadi’ Forschung? Eine kritische Untersuchung Von G.H.A Juynboll: Nāfi' Mawlā of Ibn Umar, and His Position in Muslim hadis Literature." Der Islam, vol 73, issue 2, 1996: 193-231. [doi: https://doi.org/10.1515/islm.1996.73.2.193]

Motzki, Harald. "Hadīth: Origins and Developments", dalam Harald Motzki (ed.), The Formation of the Classical Islamic World: Hadith. Aldershot, Hant: Ashgate, 2004.

Powers, David S. "The Will of Sa'd b. Abī Waqqās: a Reassessment." Studia Islamica, vol. LVIII, 1989: 33-53. [doi: https://doi.org/10.2307/1595341]

Speight, R. Marston. "The Will of Sa'd b. Abī Waqqās: The Growth of Tradition." Der Islam, vol 50, issue 2, 1973: 249-267. [doi: https://doi.org/10.1515/islm.1973.50.2.249]

Speight, R. Marston. "A Look at Varian Readings in the Hadith.” Der Islam, vol. 77, issue 2, 2000: 167-179. [doi: https://doi.org/10.1515/islm.2000.77.1.169]

Speight, R. Marston. "Oral Traditions of the Prophet Muhammad: A Formulaic Approach." Oral Tradition, IV/1-2, 1989: 27-37.

Syaraf al-Qudāh dan Amīn al-Qudāh, Asbāb Ta'addud al-Riwwāyāt fì Mutūn al-Hadìs al-Nabawì al-Syarif. Jordan: Dār al-Furqān, 1985.

Shayuthy b. Abdul Manas, Ta'addud al-Riwà̃yāt fì Matn al-Hadìs al-Nabawì Asbäbubu wa Áśärubu. Disertasi Doktor IIUM, 2004.

Ulummudin. "Pemetaan Penelitian Orientalis terhadap Hadis Menurut Harald Motzki." al-Bukhari, vol, 3, no 1, 2020: 86-104. [doi: https://doi.org/10.32505/al-bukhari.v3i1.1468 ]

Wensinck, A.J.. "The Importance of Tradition for The Study of Islam." The Muslem World, vol 11, 1921: 239-245. [doi: https://doi.org/10.1111/j.1478-1913.1921.tb01858.x]

Yilmaz, Rahile. "Robert Marston Speight." Hadis Tetkikleri Dergisi, vol. 12, no. 1, 2014: 175-179.

Zaman, Iftikhar. The Evolution of $A$ Hadith: Transmission, Growth and the Science of Rijal in a Hadith of Sa'id b. Abi Waqqas. Disertasi, University of Chicago, 1991. 